\title{
POETRY
}

\section{Quartet of remembrance}

Look at the wrinkling fruit on the counter in the basket. I wonder if I should pick it up.

I think I remember when it looked appetizing. Maybe it will get eaten.

I see you running in the school ground. When did you get so tall my love? It feels like I have forgotten when you grew. I don't want you to leave.

Our old apartment seemed so small. When did we bring all this into our house? I can't seem to throw these things away. Perhaps when we move.
Look at the peeling paint on the steps. I wonder if we should repaint them.

I think we should choose a different colour. Maybe we should do this next year.

\section{Ian Scott MD MSc DOHS}

Undergraduate Family Practice Programs Director University of British Columbia

Vancouver, BC

"Quartet of Remembrance" received an honourable mention in the 2011 ARS Medica and CMAJ Humanities Poetry and Prose contest, announced at the 2011 Canadian Conference on Medical Education.

CMAJ 2012. DOI:10.1503/cmaj.111092 